\title{
Biologiczne podstawy emocji. Rola stresu w regulacji procesu dojrzewania
}

\section{Wstęp}

Słowo „emocja” pochodzące od łacińskiego „ex movere” (poruszyć, podniecić) jest na ogół rozumiane różnie przez filozofów i biologów. Filozofowie często uważali je za prymitywne reakcje organizmu różne bodźce z otoczenia, za antytezę rozumu. Przyrodnicy zainteresowali się emocjami stosunkowo późno. Darwin widział w nich pozostałości po wcześniejszych etapach ewolucyjnego rozwoju. Prawie przez cały XX w. emocje budzily niewielkie zainteresowanie naukowców, którzy koncentrowali się głównie na badaniu „rozumu”, uważanego za istotę człowieczeństwa. Freud pasjonował się patologicznymi emocjami i analizował ich wpływ na psychikę i zachowanie człowieka. Współcześni biolodzy uważają emocje za spontaniczne, nieuświadomione reakcje organizmu na ważne sytuacje życiowe, które bezpośrednio lub pośrednio decydują o jego bezpieczeństwie i przetrwaniu. Emocje jako odruchy występują we wszystkich organizmach, nawet $\mathrm{w}$ jednokomórkowych, które reagują na bodźce awersyjne próbami obrony lub ucieczki. Odruchy te można nazwać pierwotnymi formami emocji.

Ogromny postęp w naukach przyrodniczych, jaki dokonał się po II wojnie światowej dzięki wkroczeniu do nauki dużych zastępów badaczy w Europie, USA i Azji, zaowocował poznaniem mechanizmów biologicznych i molekularnych leżących u podstaw funkcjonowania organizmu, w tym mózgu. Poznanie tajemnic mózgu w sposób naturalny rozbudziło zainteresowanie emocjami, podjęto więc próby ich badania oraz interpretowania w oparciu o zjawiska biologiczne. Neurobiolodzy uważają emocje za integralną funkcję ludzkiego mózgu, która odgrywa krytyczną rolę w podejmowaniu właściwych życiowych decyzji. Rozróżniają trzy etapy emocji: (I) stan emocji - stan fizjologicznego wzbudzenia, uruchamiany w mózgu automatycznie i nieświadomie w życiowo walentnych okolicznościach; (II) stan uczucia, który może być reprezentowany nieświadomie i cechuje się stereotypową ekspresją, behawioralną, taką jak mimika, postawa, czy wokalizacja, które służą komunikacji; i (III) uświadomiony subiektywny stan uczucia i emocji. 
Podstawowe emocje takie jak strach, złość, smutek, radość, obrzydzenie, zdziwienie, zaciekawienie, akceptacja są wbudowane w naturę ssaków i są niezbędne dla przetrwania w grupie. Mimiczno-behawioralne ekspresje emocji są uniwersalnym językiem, wspólnym dla wszystkich ludzkich kultur, a nawet językiem ponadgatunkowym. Emocje są często odczuwane jako stereotypowe sensacje ciała. Strach czy złość odczuwane są przez przyśpieszone bicie serca i napięcie mięśniowe, smutek - przez ściśnięcie gardła, napięcie oczu, zrelaksowanie kończyn, radość przez poczucie lekkości i ekspansji. Emocjom wstydu towarzyszą uderzenia gorąca na twarzy i szyi, pożądaniu - przyśpieszony oddech i bicie serca. Płacz, śmiech, drżenie, pocenie się to automatyczne reakcje, które rozładowują emocje. Różnym emocjom towarzyszą charakterystyczne mimiczne ekspresje.

Emocje złożone takie jak miłość, przywiązanie, przyjaźń, współczucie, zazdrość, duma są pochodnymi podstawowych emocji lecz przedłużonych w czasie, a więc trwalej zakodowanymi w pamięci. Wydaje się, ze wyewoluowały one jako środek umoźliwiający przetrwanie stada, plemienia czy gatunku, gdyż są niezwykle istotne dla sukcesu rozrodczego i życiowego, opieki nad potomstwem, grupowego bezpieczeństwa czy zdobywania pokarmów. \worzenie lub odtwarzanie szeroko pojętej kultury, przeżycia estetyczne czy religijne też opierają się na elementarnych emocjach, ale dodatkowo angażują wysoce wyewoluowane korowe struktury mózgu, co nadaje im unikalny, zda się dla ludzki wymiar.

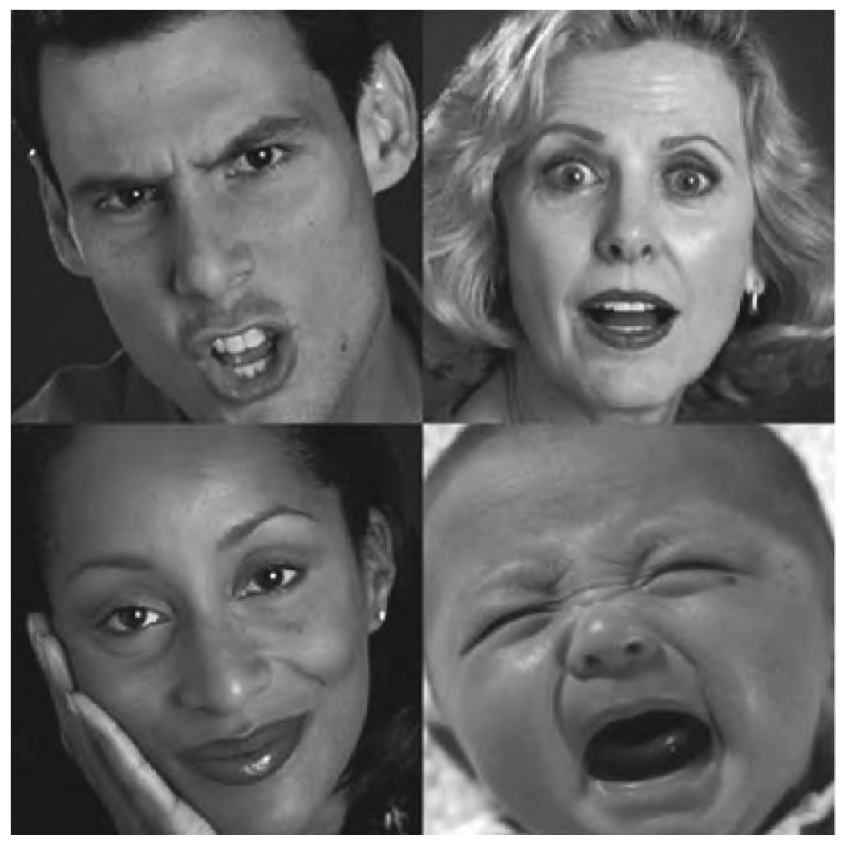

Mimiczne ekspresje emocji 


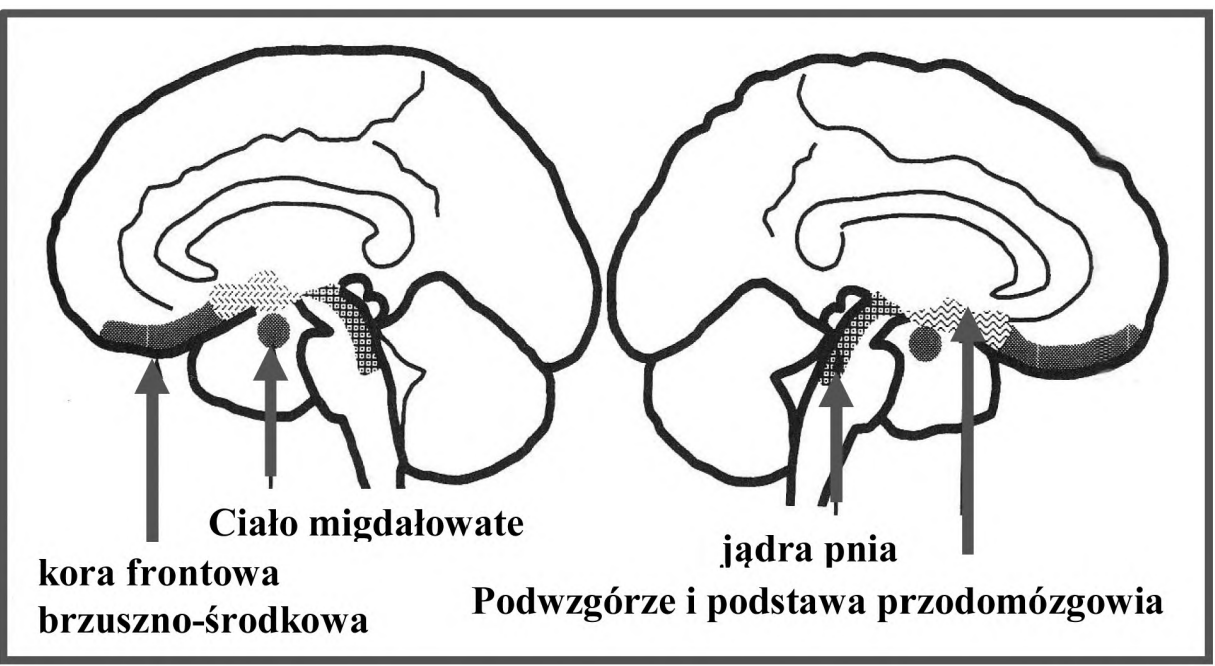

Rysunek ilustruje główne regiony mózgu, wże których rodza się emocje. Uświadamianie emocji oraz reakcje emocjonalne uaktywniają także inne struktury mózgu.

Neurobiologię emocji człowieka bada się dziś przy pomocy różnych technik obrazowania rozwiniętych w ostatnich trzech dekadach, które stanowią okno do badań żywego mózgu. Mierzą one neuroanatomię, regionalny metabolizm mózgu, lokalne reakcje biochemiczne, czy przepływ krwi. \echniki te włączają tomografię komputerową $(\bigotimes \mathrm{K})$, pozytronową lub protonową tomografię emisyjną (PEX i SPECX), oraz wizualizację rezonansem magnetycznym (MRI). Pozwoliły one ustalić, które ośrodki mózgu uczestniczą we wzbudzaniu różnych emocji.

Za metaboliczne zmiany w komórkach mózgu związane $\mathrm{z}$ emocjami odpowiedzialne jest działanie różnych neuroprzekaźników (neurotransmiterów) oraz neurohormonów. Neuroprzekaźniki z grupy amin biogennych (adrenalina, noradrenalina, serotonina i dopamina) uczestniczą w emocjach przyjemności, rozkoszy, szczęśliwości, pożądania, miłości, bądź smutku, depresji, apatii. Neurohormony oksytocyna i wazopresyna są odpowidzialne za przywiązanie, a estrogeny i testosteron za pożądanie. Neurotransmitery z grupy aminokwasów pobudzających (glutaminian) lub hamujących (GABA) uczestniczą w emocjach podniecenia, ciekawości, lęku czy uspokojenia. Leki psychotropowe, które zmieniają aktywność neuroprzekaźników w mózgu mogą całkowicie odmienić emocje, albo silnie je stłumić. Większość leków antydepresyjnych nasila aktywność amin biogennych, podobnie działają euforogenne substancje uzależniające takie jak amfetamina czy kokaina. Leki hamujące system inhibitorowego neurotransmitera, GABA, działają prolękowo, a leki nasilające ten system - wpływają uspokajająco i relaksująco. Podobnie do tych ostatnich działa alkohol. 


\section{Hormony stresowe i emocje}

Stres jest zaburzeniem homeostazy wywołanym działaniem niekorzystnych czynników fizycznych bądź psychicznych, które zmuszają organizm do nadmiernego wysiłku. Fizjologia organizmu szybko adaptuje się do stresu. Wydzielają się wówczas zwiększone ilości hormonów, które mobilizują organizm do natychmiastowej walki bądź ucieczki i umożliwiają mu przetrwanie stresowej sytuacji. Najważniejsze hormony stresowe to noradrenalina (wydzielana w mózgu) i adrenalina (wydzielana przez rdzeń nadnerczy do krwioobiegu), które przyśpieszają krążenie krwi i dostarczają do mięśni zwiększonej ilości tlenu i glukozy, pobudzają mózg, zaostrzają czujność i zwiększają szybkość reakcji. Zaś kora nadnerczy wydziela duże ilości sterydowych hormonów stresowych, które działają adaptacyjnie na cały organizm. Najważniejszy z tych hormonów to glukokortykoid, kortyzol, który mobilizuje źródła energii. Inne sterydowe hormony nadnerczy działają bezpośrednio na mózg, adaptując jego funkcje do sytuacji stresowej.

Moje badania wykonane w National Institutes of Heath w USA wykazały, że hormon sterydowy, siarczan dehydroepiandrosteronu (DHEAS), który wydziela się we wczesnej fazie stresu - stymuluje neurony, zwiększa pobudzenie mózgu, szybkość reakcji i uczenia się, podczas gdy inne sterydowe hormony takie jak tetrahydroprogesteron ( $₫ \mathrm{HP})$ i tetrahydrodeoksykortykosteron ( $\mathrm{HDOC}$ ), które wydzielają się w późniejszej fazie stresu, działają uspokajająco i chronią neurony przed uszkodzeniem wskutek nadmiernej stymulacji ${ }^{1}$. Hormony te regulują także inne systemy organizmu, takie jak układ odpornościowy i rozrodczy.

Od dawna wiadomo, że stres działając poprzez hormony stresowe reguluje procesy rozrodcze. Silny stres hamuje rozrodczość, bowiem glukokortykoidy hamują wydzielanie gonadotropin i funkcje gonad. Dlatego u dziewcząt poddanych silnym stresom, zwłaszcza fizycznym, często opóźnia się dojrzewanie lub zatrzymują się cykle miesięczne ${ }^{2}$. Natomiast stresy psychosocjalne działają zazwyczaj przeciwnie i mogą przyspieszać dojrzewanie $e^{3}$. Biologiczny mechanizm tego ostatniego zjawiska nie jest jasny, ale i on może mieć podłoże neurohormonalne. Jest prawdopodobne, że odpowiedzialny jest za to m.in. pobudzający hormon stresowy DHEAS. Wydzielanie tego hormonu przez korę nadnerczy zapoczątkowuje etap rozwojowy adrenarche, który poprzedza dojrzewanie płciowe. Wydzielany podczas stresu DHEAS działa jako stymulant i pobudza „uśpioną" u dzieci oś

Majewska M. D., Neurosteroids: endogenous bimodal modulators of the GABAA receptor. Mechanism of action and physiological significance. Prog Neurobiol. 1992, 38(4):379-95.

2 Castelo-Branco C, Reina F, Montivero AD, Colodrón M, Vanrell JA. Influence of highintensity training and of dietetic and anthropometric factors on menstrual cycle disorders in ballet dancers. Gynecol Endocrinol. 2006, 22(1):31-5.

3 Cesario SK, Hughes LA., Precocious puberty: a comprehensive review of literature. J Obstet Gynecol Neonatal Nurs. 2007, 36(3):263-74. 
HPG (podwzgórzowo-przysadkowo-gonadalną) ${ }^{4,5}$, co może przyśpieszać dojrzewanie płciowe ${ }^{6}$.

Regulacja dojrzewania płciowego i rozrodczości przez hormony stresowe ma istotne znaczenie ewolucyjne i służy przetrwaniu jednostki oraz gatunku. Zahamowanie rozrodczości podczas silnego stresu (głodu, nadmiernego wysiłku czy fizycznych zagrożeń) oszczędza witalne siły organizmu, umożliwiając mu przetrwanie kryzysowej sytuacji, jak również zapobiega narodzinom osłabionego potomstwa. Natomiast przyspieszenie płciowego dojrzewania dziewcząt w sytuacji przedłużającego się, lecz nie zagrażającego życiu stresu socjalnego, może służyć przerwaniu gatunku, gdyż zwiększa zdolności rozrodcze całej populacji, w której życie indywidualnych osobników może być (wskutek stresów) skrócone. Stres można zatem uznać za ważny motor ewolucji.

\section{SUMMARY}

Emotions are fundamental functions of mammalian brain, essential for survival of an individual, a group and a species. They have biological basis and are mediated by a variety of neurotransmitters and neurohormones acting on specific brain structures. Stress is state of disturbed homeostasis, which generates a spectrum of adaptive physiological reactions in an organism, which promote individual's survival or survival of a species. One such adaptive mechanism includes control by stress (via stress hormones) of reproductive functions by either delaying or accelerating puberty.

4 Ojeda SR, lomniczi A, Mastronardi C, Heger S, Roth C, Parent as, Matagne V, Mungenast AE. Minireview: the neuroendocrine regulation of puberty: is the time ripe for a systems biology approach? Endocrinology. 2006, 147(3):1166-74.

5 Mitsushima D, Hei DL, Derasawa E., Gamma-Aminobutyric acid is an inhibitory neurotransmitter restricting the release of luteinizing hormone-releasing hormone before the onset of puberty. Proc Natl Acad Sci U S A. 1994, 91(1):395-9.

6 Kulik-Rechberger B, Furmaga-JabŁońska W, Rechberger 囚., The role of dehydroepiandrosterone sulfate during puberty in girls. Ginekol Pol. 2000, 71(8):668-72. 